Bayero Journal of Pure and Applied Sciences, 11(1): 93 - 100

ISSN 2006 - 6996

\title{
BIOLEACHING OF SILICA SAND USING BIOREDUCING BACTERIA (Shewanella STRAINS)
}

\author{
Yahaya, S. ${ }^{1}$, Aisha B.M. ${ }^{* 1,2}$ Zegeye, A. ${ }^{3}$, Manning, D.A.C. ${ }^{3}$ and Fialips, C.I. ${ }^{3}$ \\ ${ }^{1}$ Department of Microbiology, Bayero University, Kano, Nigeria \\ ${ }^{2}$ National Biotechnology Development Agency, Federal Ministry of Science and \\ Technology, Abuja, Nigeria \\ ${ }^{3}$ School of Civil Engineering and Geosciences Newcastle University, UK \\ ${ }^{*}$ Corresponding author: aishabelmoh@gmail.com
}

\section{ABSTRACT}

Silica sand is generally not pure when mined; often associated with iron hydroxide and oxyhydroxide impurities which lowers its industrial value and requires purification before use. To join the global community towards environmental consciousness, protection and effective energy utilization, this paper considers microbial purification in a closed non-growth system as an alternative for iron removal. The anaerobic removal of $\mathrm{Fe}(\mathrm{III})$-bearing impurities from the mineral was investigated using small scale microcosm experiments conducted with $\mathrm{Fe}$ (III) in silica sand as the sole electron acceptor and lactate as the electron donor in the presence of pure cultures of Shewanella strains (S. putrefaciens CIP8040, S. putrefaciens CN32, S. oneidensis MR-1, S. algae BrY and S. loihica) and anthraquinone 2,6 disulphonate (AQDS) serving as electron shuttling mediator. The reduction of $\mathrm{Fe}(I I I)$ from silica sand was measured as the production of $\mathrm{Fe}(\mathrm{II})$ in $\mathrm{HCl}$ extracts using modified p-Phenanthroline techniques. Absorbance was measured using UV vis-spectrophotometry at $510 \mathrm{~nm}$. Up to $17.6 \%$ of the iron bearing impurities $\left(117 \mathrm{mg}\right.$ of bioreducible $\mathrm{Fe}_{2} \mathrm{O}_{3}$ per $100 \mathrm{~g}$ of silica sand) was successfully removed after 15 days. Addition of AQDS as electron transport mediator enhanced the rate and extent of bioreduction by facilitating the exchange of electrons between the iron reducing bacteria and the iron-bearing phase in the mineral. This study revealed that all the selected commercially available Shewanella strains tested were able to reduce and leach iron (III) from Silica sand by coupling oxidation of lactate to anaerobic respiration except Shewanella loihica whereas Shewanella algae BrY was the most efficient. Keywords: Silica sand, iron impurities, iron reducing bacteria, Shewanella strains, bioreduction.

\section{INTRODUCTION}

Silica sand is a versatile industrial mineral extensively used in glass manufacturing industries (Styriakova et al., 2007), construction, chemical industries and optical data transmission. In the glass manufacturing industries, it is used in the production of sheet glasses for windows, bottles, mirror, optical instruments, chemical apparatus, electrical insulation, condensers, automobiles, aircraft bodies, filters, building blocks, abrasives and for gravel packing in the petroleum industries. Other applications include light bulbs and fluorescent tubes, TV, computer screens and glass fibers that are used for insulation and reinforcement (British, 2009a). When mined, Silica sand is generally not pure, often associated with iron hydroxide and oxyhydroxide impurities (ranging between 0.074 up to $44.2 \mathrm{mg}$ Fe per gram of mineral) usually in the form of $\mathrm{Fe}^{3+}$-phases adsorbed onto the mineral surface, covering the entire mineral surface, or admixed as a separate iron bearing phase (Yahaya, 2011). Industrial application of silica sand can be limited by the presence of a heavy metal content particularly iron (Banza et al., 2006) and for glass manufacturing, silica sand must contain a very low amount of iron (Zhao et al., 2007). The permissible $\mathrm{Fe}_{2} \mathrm{O}_{3}$ content in glasses sands of different grades should not be more than $0.05 \%$ for house hold glasses, $0.012-0.02 \%$ in clear glasses, 0.025 $0.035 \%$ in crystal glasses, $0.07 \%$ in light engineering and medical glasses and $0.09-0.20 \%$ in sheet glasses (Styriakova et al., 2010). The presence of iron generally affects the transparency of glasses, impairs transmission in optic fibers and also lowers the melting point of refractory materials (Mowla et al., 2008). The associated irons impurities can be found as iron hydroxides coating the entire quartz mineral grain and are reported to bind strongly on the surface of quartz silica in various surfaces of sand thereby make it rusty in appearance (Rusch et al., 2010; Zhao et al., 2007). 
However, these iron oxy--hydroxide coatings are generally characterised as the minerals ferrihydrite, hematite, goethite and lepidocrocite, with the iron content in the various oxide phases usually ranging between 0.074 and $44.2 \mathrm{mg} \mathrm{Fe}$ per gram of sand in various soils and sediment (Rusch et al., 2010). Removal of iron impurities from Fe(III)- bearing in silica sand using conventional methods is reported to be quite expensive and environmentally unfriendly due to the waste generated (Hosseini et al., 2007; Styriakova et al., 2007; Lee et al., 2002). This study highlighted the potential application of dissimilatory iron reduction mechanisms as an alternative for improving industrial value of silica sand.

\section{MATERIALS AND METHODS}

Small scale microcosm experiments were conducted with $\mathrm{Fe}(\mathrm{III})$ in silica sand as the sole electron acceptor and lactate as the electron donor in the presence of pure cultures of Shewanella cells. Anthraquinone 2,6 disulfonate was used to enhance electron shuttling in the system $[2.5 \mathrm{~g}$ Silica sand (obtained from Oakamoor Quarry, UK) $+10 \mathrm{mM}$ lactate $+100 \mu \mathrm{m}$ AQDS $+3.5 \mathrm{~mL}$ cell suspension Shewanella strains (commercially obtained) cells at $20^{\circ} \mathrm{C}$ ]. The concentrations, temperature and time were varied to obtain an optimum for the bioreduction. The reduction of Fe(III) from silica sand was measured as the production of $\mathrm{Fe}(\mathrm{II})$ in $\mathrm{HCl}$ extracts using modified phenanthroline techniques (Fadrus and Maly, 1975). The effect of temperature, cell density, slurry density, electron donor concentration, multiple cell inoculation was investigated and an assessment was made of the impact of anthraquinone-2,6-disulphonate (AQDS). Absorbance was measured using UV- spectrophotometry at $510 \mathrm{~nm}$. Liquid samples from bioleaching experiment were analysed for dissolve organic carbon using a Shimadzu TOC5050A dissolved carbon analyser equipped with an AS1-5000A autosampler. To assess any changes and improvement in mineralogy after bioleaching processes, X-ray (powder) diffraction measurements were obtained with a Philips X'pert PRO XRD system recording from 20 to $7002 \theta$ CuKa, at $0.033402 \theta$ per step and 99.70 seconds per step.

Similarly, FTIR analyses spectra of bioleached and initial minerals were measured and obtained in transmission mode using $\mathrm{KBr}$ pressed pellets $(1-2 \mathrm{mg}$ mineral in $200 \mathrm{mg} \mathrm{KBr})$ in the mid-infrared range $(400-4000 \mathrm{~cm}-1)$ on an AVATAR 360 FTIR ESP spectrometer. Mossbauer spectroscopy was conducted at $300 \mathrm{~K}$ in transmission mode. Scanning electron microscopy was also conducted to observe changes in the morphology of the mineral.

\section{RESULTS AND DISCUSSION}

Studies have demonstrated that dissimilatory iron-reducing bacteria, like Shewanella strains, can use insoluble $\mathrm{Fe}$ (III) oxide minerals as a terminal electron acceptor for energy conservation and growth which in the process transformed $\mathrm{Fe}$ (III) to $\mathrm{Fe}$ (II) at the surface of iron oxide particles. This facilitates an industrial mineral's ability to release metals which can have a profound impact on the mineral or environmental quality (Bose et al., 2009; Lee et al., 2002). The study generally involved optimisation of bioleaching processes using a small scale microcosm approach where Fe(III) removal efficiency was evaluated through examining the bioreduction potential of some selected commercially available iron reducing Shewanella strains.

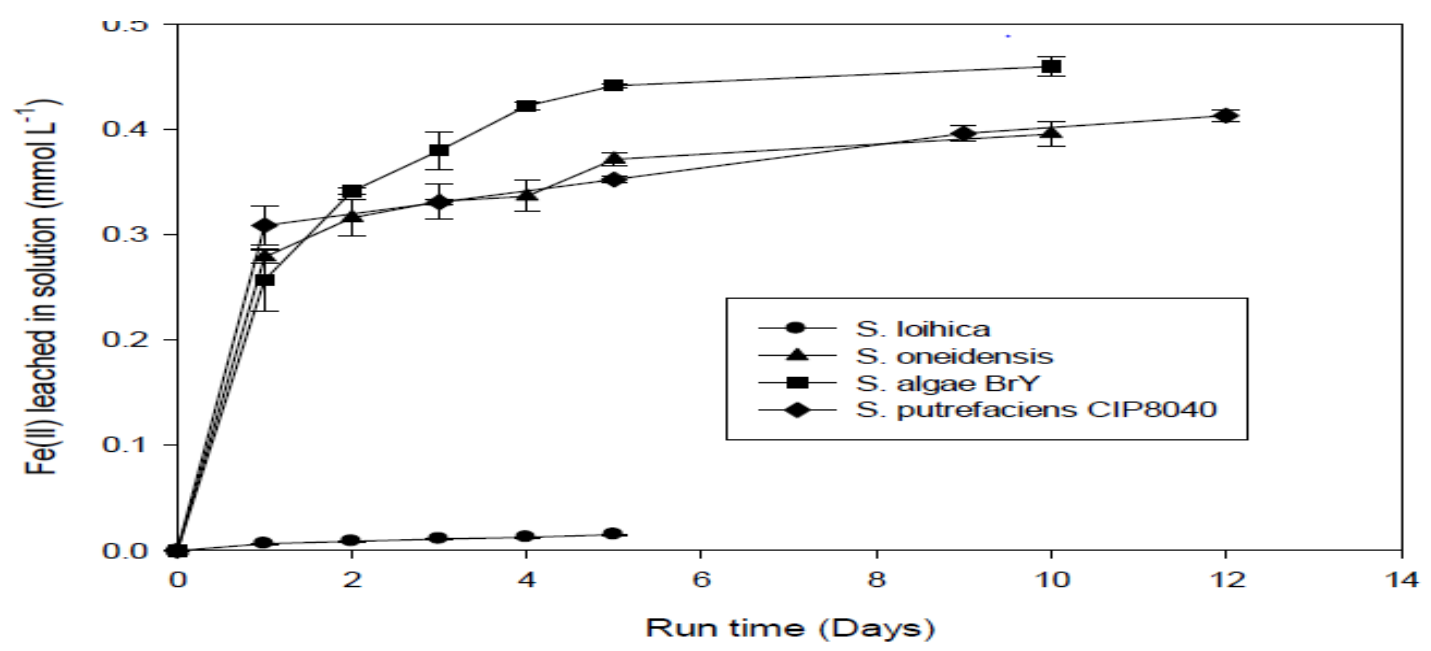

Figure 1: Line plot showing extractable Fe(II) concentration from 2.5g Silica Sand as a function of time to compare different iron-reducing Shewanella strains in the presence of $10 \mathrm{mM}$ lactate and $100 \mu \mathrm{m} A Q D S$ at $20^{\circ} \mathrm{C}$ 
Bioreduction in silica sand was tested with $\mathrm{Fe}(\mathrm{III})$ - reducing Shewanella species in the presence of lactate as the sole electron donor in the system and AQD serving as electron shuttling compound under non-growth conditions. All the Shewanella species examined here have been able to anaerobically respire and reduce $\mathrm{Fe}(\mathrm{III})$ within the silica sand, thereby coupling this reduction to the oxidation of lactate with the exception of S. loihica. S. oneidensis and S. putrefaciens CIP8040 results in similar rate and extent of $\mathrm{Fe}(\mathrm{III})$ reduction but variation in the extent of $\mathrm{Fe}$ (III) was evident with substantial reduction of $\mathrm{Fe}$ (III) using $\mathrm{S}$. algae $\mathrm{BrY}$. The strains $\mathrm{S}$. algae, $\mathrm{S}$. oneidensis and S. putrefaciens CIP8040 have been reported to utilise lactate as the typical electron donor for anaerobic respiration of solid electron acceptors (Rosenbaum et al., 2011; Anton and Terry, 2007; Konishi et al., 2007). In our system S. loihica was not effective in coupling lactate oxidation to $\mathrm{Fe}$ (III) reduction in silica sand. The observed lack of $\mathrm{Fe}$ (II) production by $\mathrm{S}$. loihica was likely not constrained by the carbon source (lactate), $\mathrm{pH}$ $(7.1-7.5)$ or temperature $\left(25-30^{\circ} \mathrm{C}\right)$ of experimental condition employed in our system, as these parameters were within the reported tolerable limits of this microorganism, suggesting that other limiting factors might be responsible.

Cell density was seen to effectively influence the bioleaching process, because substantial increases in the rate and extent of $\mathrm{Fe}(\mathrm{III})$ reduction was achieved in the presence of high numbers of cells $(7 \mathrm{ml}$ cell suspension) within the period of bioleaching, compared with and better than when half of the cell number ( $3.5 \mathrm{ml}$ cell suspension) was used for the same mass of silica sand in the presence of the same concentration of electron shuttling compound. This was also supported by the work on ferrihydrite reduction using Geobacter sulfurreducens where increase in biomass load was understood to substantially influence the rate and extent of bioreduction (MacDonald et al., 2011). Similarly, results obtained are in agreement with the work conducted by O'Loughlin, (2008) where increase in cell number improves the rate and extent of bioreduction. It is therefore clear that high bacterial cell suspension is required for an effective bioleaching of silica sand. Anthraquinone-2, 6-disulphonate (AQDS) was known to enhance electron delivery to various oxides in many minerals (Jaisi et al., 2007b; Lovley et al., 1998). However, addition of AQDS in the presence of low Shewanella cells suspensions was generally found to have no significant effect on the rate and extent of reduction when compared with the experiments that has not been added without AQDS. Although it was observed that the presenceof high numbers of cells substantially influences the initial rate of $\mathrm{Fe}$ (III) reduction. However we assumed that in the presence of fewer cells, the bioreduction process progresses slowly even when AQDS was added to promote electron delivery in the system. Hence these steady and slow progression in $\mathrm{Fe}$ (II) production over time could results into and promote precipitation of ferrous minerals such as siderite $\left(\mathrm{FeCO}_{3}\right)$ which may possibly inhibit the rate and extent of $\mathrm{Fe}$ (III) bioreduction. These observations were supported with the experiment work conducted on the role of biomass and electron shuttle for ferrihydrite reduction kinetics (MacDonald et al., 2011). AQDS and AH2QDS which could influence the initial rate and extent of $\mathrm{Fe}(\mathrm{III})$ reduction, suggesting that the rate of transfer of AH2QDS to silica sand may be slower and less than the rate of transfer of electrons from lactate to AQDS especially with the presence of few cells. Moreover, we also assume that the electron shuttle (AQDS) may have less or no effect on the bioleaching process, but Shewanella cells actively promote electron shuttling by direct contact or alternatively by other enzymatic reduction pathways because Shewanella has been proposed to have potential for direct electron transfer to insoluble Fe(III) oxides (Cutting et al., 2009; Lloyd, 2003). This could support the reason as to why the presence of high cell concentrations greatly influences the initial rate and extent of $\mathrm{Fe}$ (III) reduction in the system than in the presence of fewer Shewanella cell suspension. In this study, varying lactate concentration influences the total extent of $\mathrm{Fe}(\mathrm{III})$ reduction. Similarly, a faster rate of reduction was initially observed in all the different amendments, although lactate consumption is accompanied by microbial reduction of $\mathrm{Fe}$ (III) to $\mathrm{Fe}$ (II), but the pattern of accumulation of $\mathrm{Fe}(\mathrm{II})$ follows a zero order reaction kinetics with respect to decrease in lactate concentration. However, $\mathrm{Fe}(\mathrm{III})$ reduction ceases after the first $48 \mathrm{hr}$ of incubation particularly in experiments added with low concentration of lactate $(1 \mathrm{mM}$ lactate), but continuously progresses at slower rate in those experiments containing high concentration of lactate $(5,10,15 \mathrm{mM}$ lactate). The slow progression and cessation of $\mathrm{Fe}(\mathrm{III})$ reduction after the first initial injection of the cell suspension may partly be attributed to possible decline in cell viability or may be related to $\mathrm{Fe}(\mathrm{II})$ adsorption on cell surfaces but is not limited by lactate concentration. 
Generally, $\mathrm{Fe}$ (II) sorption decreases cell activities and viability in a way that could limit the rate and extent of $\mathrm{Fe}$ (III) reduction (Urrutia et al.,1998). Similarly saturation on the surface of $\mathrm{Fe}$ (III) mineral with $\mathrm{Fe}(\mathrm{II})$ has been demonstrated in batch experiments as a dominant factor that promotes cessation of $\mathrm{Fe}$ (III) reduction by several iron-reducing bacteria in batch experiments (Roden and Zachara, 1996). Subsequently, when fresh cells were added after initial cessation, further bioreduction of $\mathrm{Fe}$ (III) in silica sand resumes immediately, most apparently in cultures containing low concentration of lactate $(5 \mathrm{mM}$ lactate). Bioreduction continues to linearly progresses in cultures containing high concentration of lactate without a noticeable lag period. This result is consistent with previous investigations confirming that addition or multiple inoculation of fresh metabolically active cells results into resumption of $\mathrm{Fe}$ (III) bioreduction (Jaisi et al., 2007b; Urrutia et al., 1998). Possible explanations for resumption of $\mathrm{Fe}$ (III) bioreduction are that, bioreducible $\mathrm{Fe}$ (III)- surface sites were available but the initial cells were unable to have access to them due to $\mathrm{Fe}(\mathrm{II})$ sorption on their surface as well as occlusion by $\mathrm{Fe}(\mathrm{II})$ precipitates, or $\mathrm{Fe}(\mathrm{II})$ being transferred from Fe-oxide surface to a clean cell surface thus revealing free oxide surface for further bioreduction (Urrutia et al., 1998).

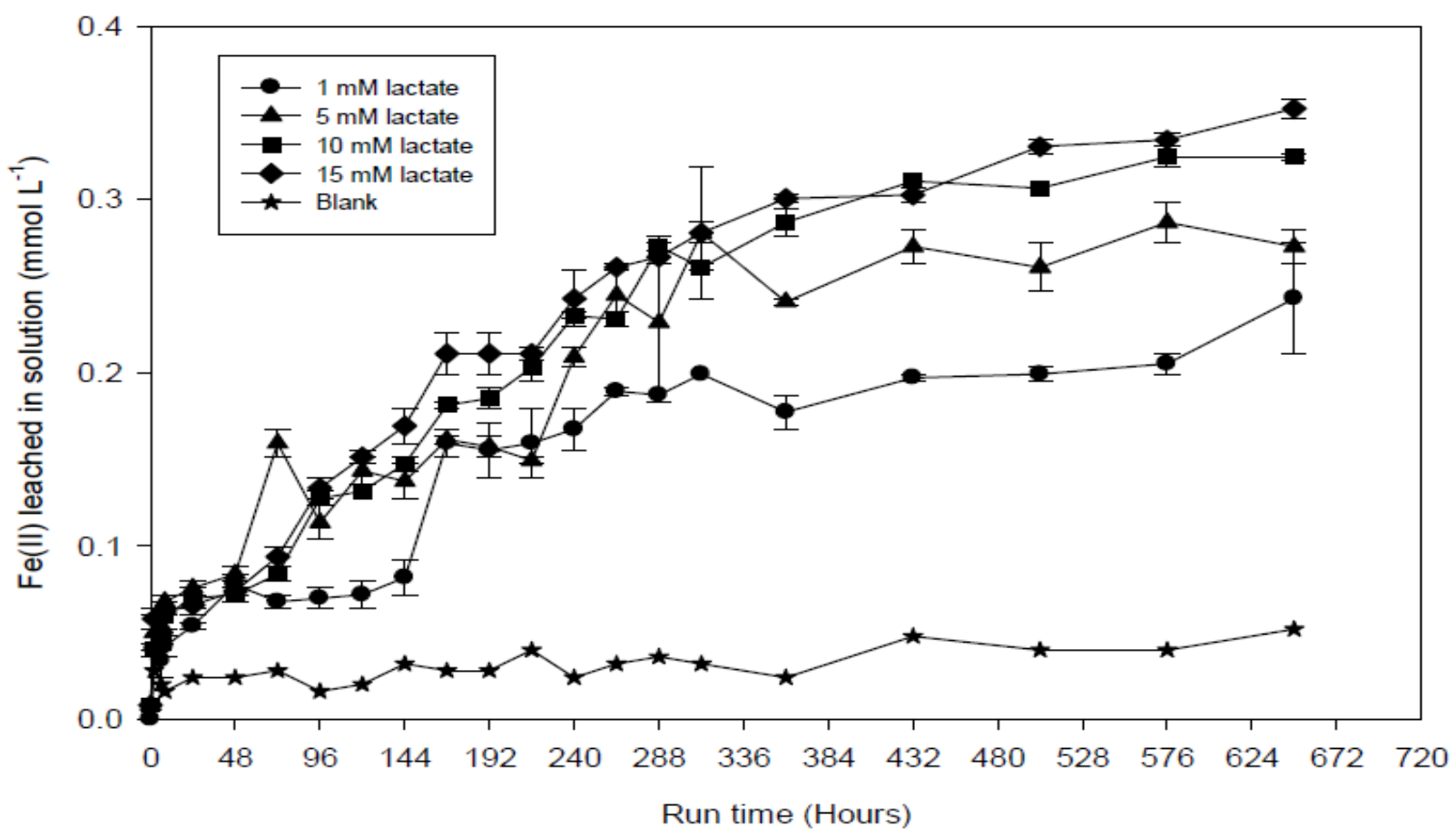

Figure 2: Bioreduction of Silica Sand under different concentration of electron donor $(1-15 \mathrm{mM}$ lactate) and multiple inoculations of S. putrefaciens CIP8040 at $30^{\circ} \mathrm{C}$. Error bars represent standard error for three replicates.

Assessment of the mineralogy after bioreduction confirms a clear XRD pattern of typical crystalline quartz as the major mineral. Pattern obtained the characteristic quartz peaks remain the same after biotreatment showing no significant changes in the mineral composition between biotreated and untreated silica sand, even though $\mathrm{Fe}(\mathrm{II})$ is measured in the solution. This shows that the crystallinity of quartz was not affected by the bioleaching process, and hence no other crystalline by- products are evident. FTIR spectra obtained from mid- infrared region clearly display bands that generally characterise the mineral to compose of mainly quartz sand confirm the predominance of quartz. The band displayed at 3500 and $3700 \mathrm{~cm}-1$ which characterise the quartz surface to be more intense in the initial untreated samples compared to biotreated samples and a blank sample that was not treated with cells. 


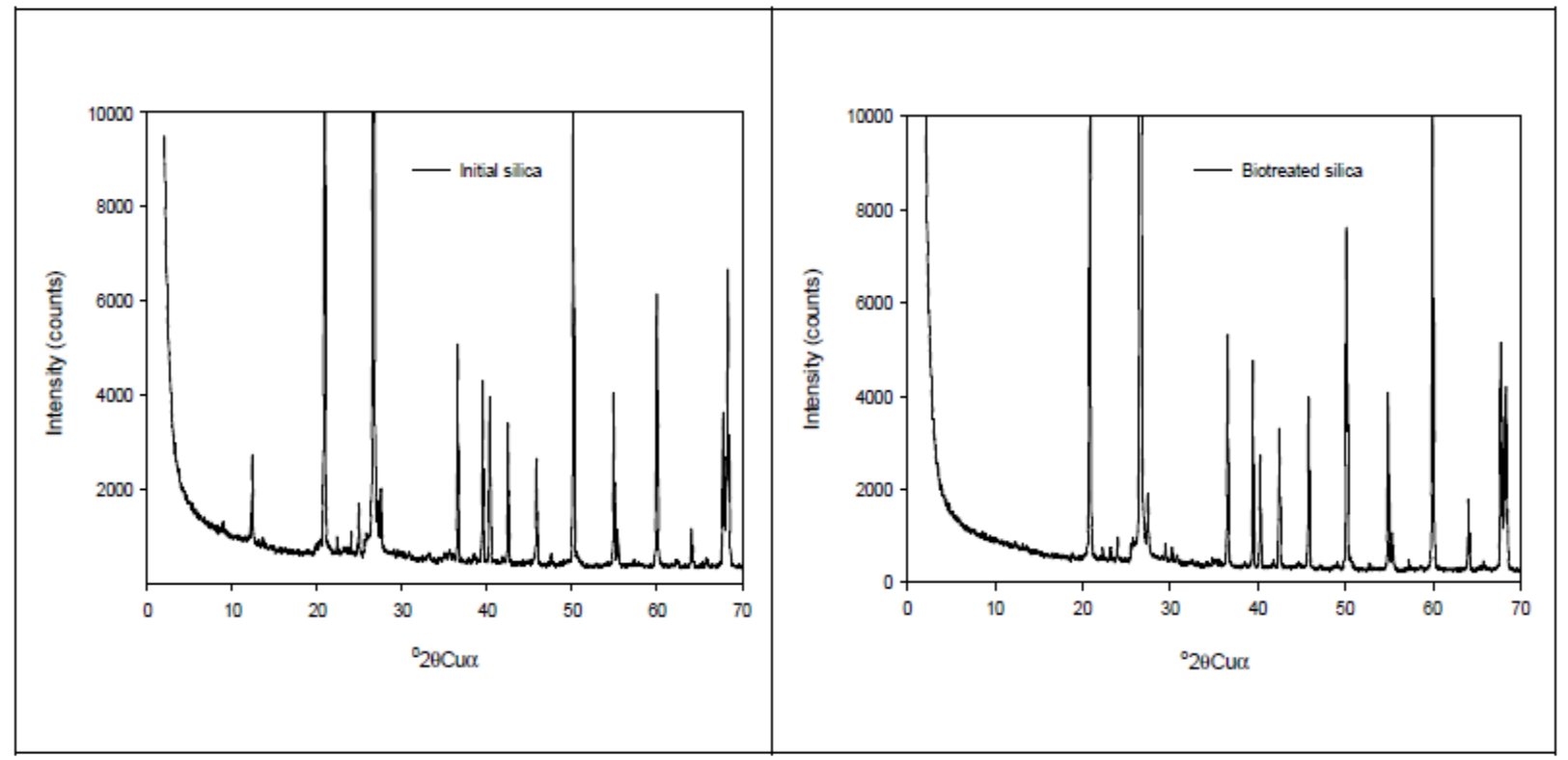

Figure 3: XRD pattern of Silica sand before and after bioreduction with S. putrefaciens CIP8040 at $30^{\circ} \mathrm{C}$ (Defined XRD was observed, with all peaks clearly resolved. There was no difference in the pattern of untreated and biotreated silica sand after 15 days of biotreatment).

SEM observation reveals on the untreated silica particle surface some fine sub-particles of irregular shapes and sizes (Figure 4). Disappearance of these particles covering the untreated quartz samples was evident after biotreatment with Shewanella putrefaciens CIP8040 suggesting bioreduction and transformation of surface Fe-oxides after bioreduction. The surface EDX analysis of quartz grains also confirms changes in bulk mineralogical composition with \%Fe content decreasing or simply decreased beyond detection limit of the analytical technique after bioreduction with Shewanella cells. Mossbauer spectroscopy on the untreated silica sand confirms the presence of the $\mathrm{Fe}^{3+}$ doublet to be corresponding to a dominant iron phase having the relative abundance of $77.5 \%$ and the remaining percentage constituted mainly of $\mathrm{Fe}^{3+}$ in their nanophases. This indicates that the silica mineral contains readily bioavailable iron phases amenable for bacterial reduction.

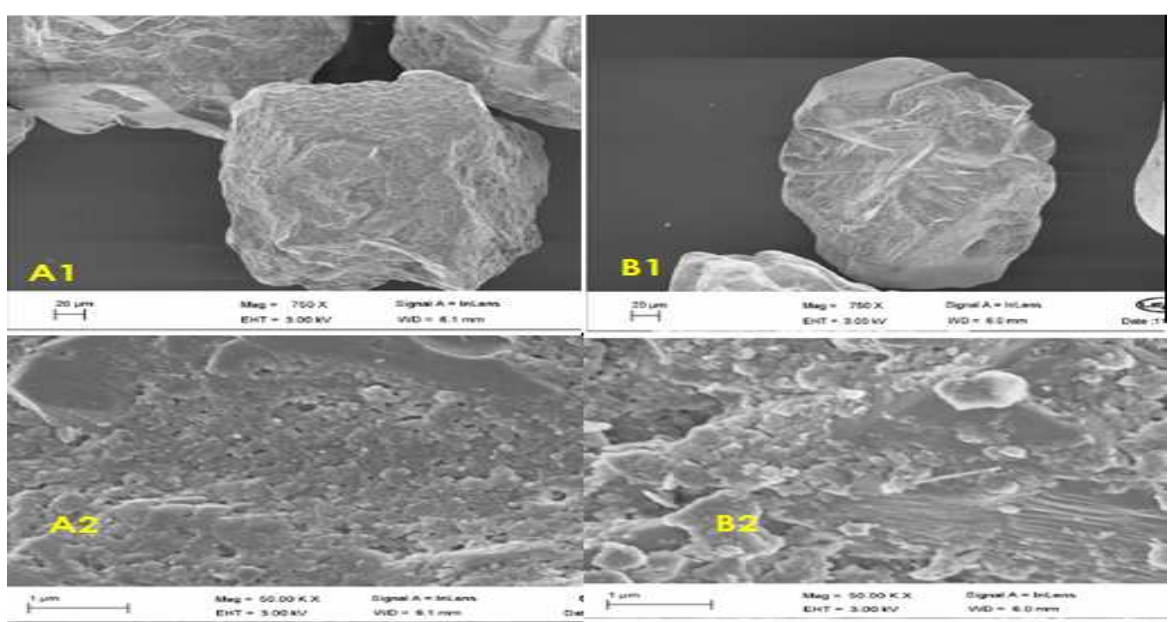

Figure 4: SEM micrographs observed before bioreduction have shown some small particles partially covering the surface of the untreated mineral (A1 \& A2). These particles were not seen after biotreatment ( $B 1 \&$ \& $B 2$ ) suggesting that the particles covering the grains are removed by the bioleaching process

Apart from assessing the potential of different Shewanella strains on the rate and extent of bioreduction in silica sand, other factors were identified to influence the rate and extent of the bioleaching process. The rate and extent of $\mathrm{Fe}(\mathrm{III})$ reduction was observed to be dependent on temperature. A temperature of around $30^{\circ} \mathrm{C}$ was the identified optimal temperature required by Shewanella putrefaciens CIP8040 for effective bioleaching although bioleaching was also observed at elevated temperature of $36^{\circ} \mathrm{C}$ and at a low temperature of $20^{\circ} \mathrm{C}$. 
The solid to liquid ratio (slurry density) is paramount in the bioleaching process because deploying more mineral for a given liquid volume and constant bacterial biomass produces greater bioleaching rate and extent than deploying a smaller mineral mass. Furthermore the overall rate of $\mathrm{Fe}$ (III) reduction depends also on the cell density because substantial amounts of iron were removed in the presence of high cell density than low cell density.

In addition, the rate and extent of bioreduction directly depends on the concentrations of electron donor (lactate) present. More iron was removed in the presence of high concentration of lactate $(10-20 \mathrm{mM})$ than in the presence of low concentration $(0.1 \mathrm{mMlactate})$. Moreover, addition of metabolically active cells after initial cessation of $\mathrm{Fe}$ (III) reduction was observed to rapidly increase the rate of reduction with a low concentration of electron donor $(0.5 \mathrm{mM}$ lactate), but gradual and linear resumption of $\mathrm{Fe}(\mathrm{III})$ reduction was seen when a high concentration of electron donor $(5-20 \mathrm{~mm}$ lactate) was added in experiments.

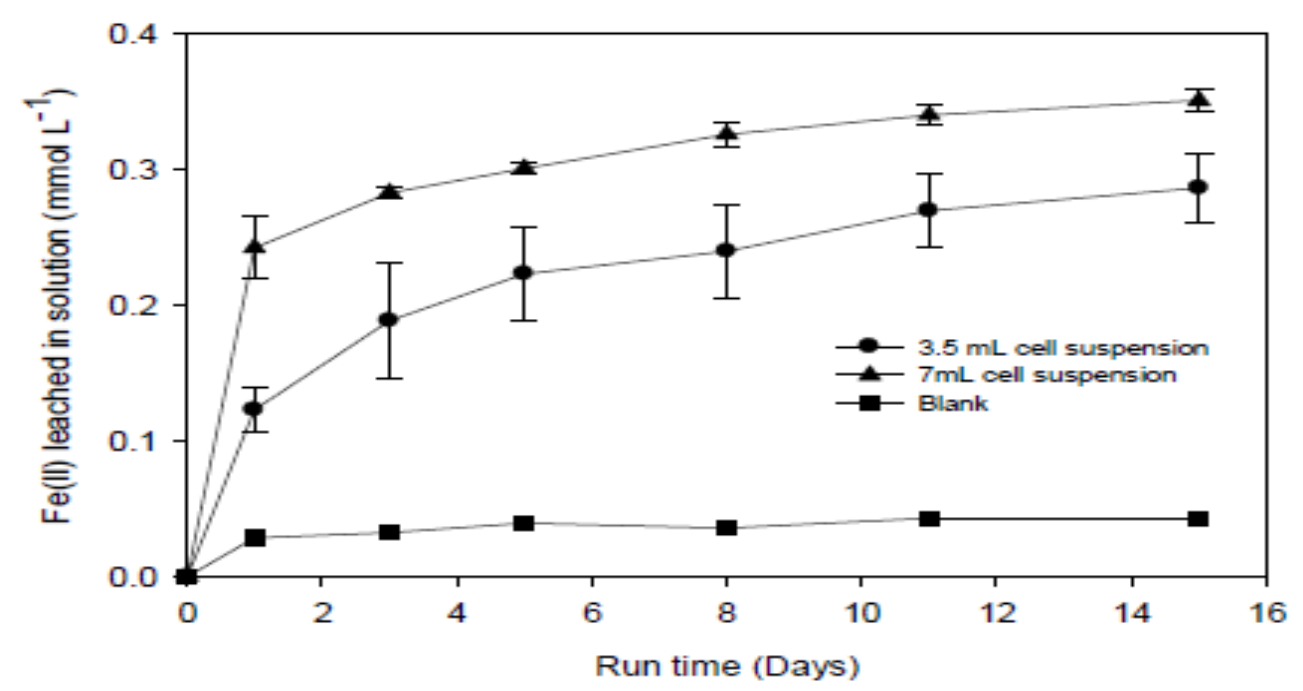

Figure 5: Bioreduction of Fe(III) from 2.5g Silica Sand using different injection of S. putrefaciens CIP8040 cell suspension $(1.2 \pm 0.4 \times 108 \mathrm{CFU} / \mathrm{mL})$ at $30^{\circ} \mathrm{C}$. Error bars represent standard error for three replicates.

The effects of electron transfer mediators were demonstrated using AQDS (anthraquinone2,6 disulphonate - a humic acid analogue). It was found that addition of AQDS greatly influenced and enhanced the overall rate and extent of bioreduction in comparison to experiments without AQDS. This is because the AQDS alleviates the need for Shewanella cells to establish a direct physical contact with the insoluble $\mathrm{Fe}(\mathrm{III})$ oxides in the mineral.

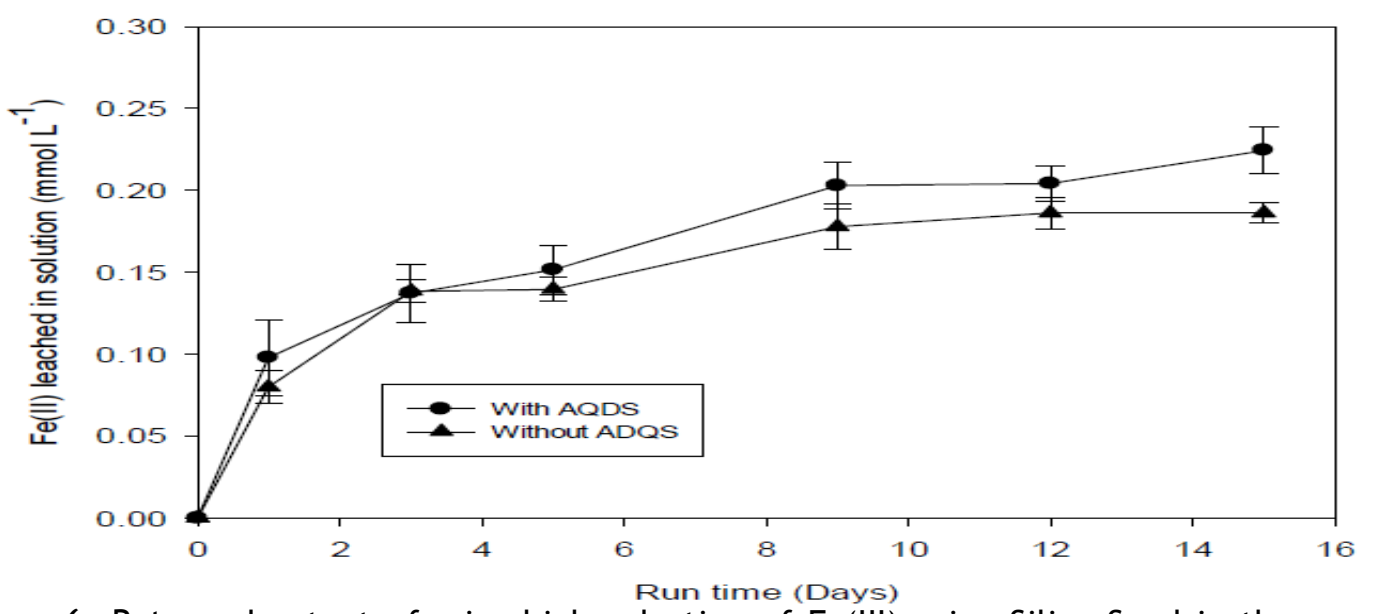

Figure 6: Rate and extent of microbial reduction of $\mathrm{Fe}(\mathrm{III})$ using Silica Sand in the presence and absence of AQDS at $30^{\circ} \mathrm{C}$ with the injection of $4 \mathrm{ml}$ of $S$. putrefaciens CIP8040 cell suspension at 1.2 $\mathrm{x} 108 \mathrm{CFU} / \mathrm{mL}$

The work reported in this paper has shown that dissimilatory iron reduction is an important process that can be used for the biorefinement of $\mathrm{Fe}$ (III)-containing minerals most particularly silica sand. 


\section{CONCLUSION}

Bioleaching of $\mathrm{Fe}(\mathrm{III})$-bearing impurities from the Silica sand using small scale microcosm experiments with $\mathrm{Fe}(\mathrm{III})$ in silica sand as the sole electron acceptor was conducted. All the commercially available iron-reducing bacteria tested in this research except Shewanella loihica were able to reduce and leach iron (III) in silica sand. Among the selected Shewanella strains used, Shewanella algae BrY was the most suitable organism for the bioreduction in small scale experiments. Rate and extent of microbial reduction of $\mathrm{Fe}$ (III) in Silica Sand in the presence of AQDS has increased and no alteration in mineralogical pattern of Silica sand was observed after biotreatment with all Shewanella strains. Microbial removal of iron in these minerals could be a suitable way for improving their quality and industrial value considering the environmental, operational, economic and technological disadvantages

\section{REFERENCES}

Anton, K. and Terry, J. B. (2007) 'The surface physicochemistry and adhesiveness of Shewanella are affected by their surface polysaccharides', Microbiology, 159, pp.1872- 1883.

Banza, A. N., Quindt, J. and Gock, E. (2006) 'Improvement of the quartz sand processing at Hohenbocka', International Journal of Mineral Processing, 79, (1), pp. 76-82.

Bose, S., HochellaJr, M. F., Gorby, Y. A., Kennedy, D. W., McCready, D. E., Madden, A. S. and Lower, B. H. (2009) 'Bioreduction of hematite nanoparticles by the dissimilatory iron bacterium ShewanellaoneidensisMR-1', Geochimica et CosmochimicaActa,73, (4), pp. 962976.

British Geological Survey, (2009a) 'Silica sand. Mineral Planning Factsheet. Community and Local Government. British Geological Survey, access on 17/03/2011', (www.bgs.ac.uk/downloads/start.cfm?i $\mathrm{d}=1369)$.

Cutting, R. S., Coker, V. S., Fellowes, J. W., Lloyd, J. R. and Vaughan, D. J. (2009) 'Mineralogical and morphological constraints on the reduction of $\mathrm{Fe}(\mathrm{III})$ minerals by Geobactersulfurreducens', Geochimica et CosmochimicaActa, 73, (14), pp. 4004-4022.

Fadrus, H. and Maly, J. (1975) 'Supression of Iron(III) Interference in the Determination of Iron (II) in Water by the 1,10-Phenanthroline Method.', Analyst, 100, pp. 549 - 554. posed by the convention chemical and physical methods widely used.

\section{Recommendations}

This paper has explored the possibility of using iron-reducing bacteria for the bioreduction of silica sand, but there are still few areas that may require further attention in order to optimize the bioleaching process for full commercial application and benefit.

Replication of the study by isolation of indigenous iron-reducing bacteria that may be present in the fresh silica sand with the intention of comparing their iron reduction potential with the commercially available iron reducing bacteria. This should be further tested to see if the indigenous iron reducers will produce better bioleaching of the mineral.

Microbiological refining of these iron bearing minerals should be considered for commercial pilot scale application.

Hosseini, M. R., Pazouki, M., Ranjbar, M. and Habibian, M. (2007) 'Bioleaching of iron from highly contaminated Kaolin clay by Aspergillusniger', Applied Clay Science, 37, (3-4),pp. 251-257.

Jaisi, D. P., Dong, H., Kim, J., He, Z. and Morton, J. P. (2007a) 'Nontronite particle aggregation induced by microbial $\mathrm{Fe}(\mathrm{III})$ reduction and exopolysaccharide production', Clay and Clay Minerals, 55, (1), pp. 96 - 107.

Jaisi, D. P., Dong, H. and Liu, C. (2007b) 'Influence of biogenic $\mathrm{Fe}(\mathrm{II})$ on the extent of microbial reduction of $\mathrm{Fe}(\mathrm{III})$ in clay minerals nontronite, illite, and chlorite',Geochimica CosmochimicaActa, 71, (5), pp. 11451158.

Konishi, Y., Ohno, K., Saitoh, N., Nomura, T., Nagamine, S., Hishida, H., Takahashi, Y. andUruga, T. (2007) 'Bioreductive deposition of platinum nanoparticles on the bacterium Shewanella algae', Journal of Biotechnology, 128, (3), pp. 648-653.

Lee, E. Y., Cho, K. S. and WookRyu, H. (2002) 'Microbial refinement of kaolin by iron reducing bacteria', Applied Clay Science, 22, pp. 47-53.

Lloyd, J. R. (2003) 'Microbial reduction of metals and radionuclides', FEMS Microbiology Reviews, 27, (2-3), pp. 411-425.

Lovley, D. R., Fraga, J. L., Blunt-Harris, E. L., Hayes, L. A., Phillips, E. J. P. and Coates, J. D.(1998) 'Humic Substances as a Mediator for Microbially Catalyzed Metal Reduction', Actahydrochimica et hydrobiologica, 26, (3), pp. 152-157. 
MacDonald, L. H., Moon, H. S. and Jaffe, P. R. (2011) 'The role of biomass, electron shuttles, and ferrous iron in the kinetics of Geobacterdevisulfurreducens mediated ferrihydrite reduction', Water Research, 45, (3), pp. 1049-1062.

Mowla, D., Karimi, G. and Ostadnezhad, K. (2008) 'Removal of hematite from silica sand ore by reverse flotation technique', Separation and Purification Technology, 58, (3), pp. 419-423.

O'Loughlin, E. J. (2008) 'Effect of Electron Transfer Mediators on the Bioreduction of Lepidocrocite ( $\gamma-\mathrm{FeOOH})$ by ShewanellaputrefaciensCN32', Environ. Sci. Technol.,42, pp. 6876 - 6882.

Roden, E. E. and Zachara, J. M. (1996) 'Microbial Reduction of Crystalline Iron(II) Oxides: Influence of Oxide Surface Area and Potential for Cell Growth', Environmental Science \& Technology, 30, (1618 - 1628).

Rosenbaum, M. A., Bar, H. Y., Beg, Q. K., Segre, D., Booth, J., Cotta, M. A. and Angenent, L. (2011)'Shewanellaoneidensisin lactate-fed pure-culture and a glucosefed coculture with Lactococcus lactis with an electrode as electron acceptor', Bioresource Technology, 102, (3), pp. 2623-2628.
Rusch, B., Hanna, K. and Humbert, B. (2010) 'Coating of quartz silica with iron oxides:Characterization and surface reactivity of iron coating phases', Colloids and Surfaces $A$ : Physicochemical and Engineering Aspects, 353, (2-3), pp. 172-180.

Styriakova, I., Styriak, I., Malachovsky, P., Vecera, Z. and Kolousek, D. (2007) 'Bacterial clay release and iron dissolution during the quality improvement of quartz sands', Hydrometallurgy, 89, (1-2), pp. 99-106.

Styriakova, I., Jablonovska, K., Mockovciakova, A., Bekeniyova, A., Styriak, I., Kraus, I.,Osacky, M. and Lovas, M. (2010) 'Dissolution of iron from quartz sands by basin bioleaching under static in-situ conditions', Hydrometallurgy, 104, (34), pp. 443-447.

Urrutia, M. M., Roden, E. E., Fredrickson, J. K. and Zachara, J. M. (1998) 'Microbial and surface chemistry controls on reduction of synthetic $\mathrm{Fe}$ (III) oxide minerals by the dissimilatory iron-reducing bacterium Shewanella alga ', Geomicrobiology15, pp.269 - 291.

Yahaya, S. (2011) Bacterial Removal of Iron Impurities to Increase the Quality and Value of Industrial Minerals. Newcastle University School of Engineering and Geosciences.

http: / /hdl.handle.net/10443/1346

Zhao, H. L., Wang, D. X., Cai, Y. X. and Zhang, F. C. (2007) 'Removal of iron from silica sand by surface cleaning using power ultrasound', Minerals Engineering, 20, (8), pp. 816-818. 